THE EFFECT OF INNOVATION ON HOTEL MARKET VALUE

\author{
Juan L. Nicolau \\ Dept. of Marketing \\ Faculty of Economics \\ University of Alicante \\ PO Box 99 \\ 03080 Alicante \\ SPAIN \\ e-mail: jl.nicolau@ua.es \\ María Jesús Santa-María \\ Dept. of Applied Economics and Economic Policy \\ Faculty of Economics \\ University of Alicante \\ PO Box 99 \\ 03080 Alicante \\ SPAIN \\ e-mail: mj.santamaria@ua.es
}




\title{
THE EFFECT OF INNOVATION ON HOTEL MARKET VALUE
}

\begin{abstract}
The purpose of this article is to analyze the effect of hotel innovations on firm value. Specifically, this study fills a research gap in the previous literature by examining this effect through market value and by distinguishing the potential different impact of distinct innovation types: product, process, organization and marketing. This research contributes to consolidating the empirical evidence of hotel innovation and performance, by analyzing whether distinct types of innovation lead to different levels of results. The findings show that innovations are perceived to have a positive impact on the future sales of the company: in a four-day period $(0,+3)$, there is an increase in returns of $1.53 \%$, which is equivalent to annual returns of $300 \%$. In terms of innovation types, process and marketing innovations are found to have a higher positive effect on hotel market value than product and organization innovations; which is explained by the potential cost differences among innovations.
\end{abstract}

Keywords: innovation; market value; hotel industry. 


\section{INTRODUCTION}

Innovation is a critical element in today's service companies, in general (Hipp and Grupp, 2005; Forsman, 2011; Gallouj and Weinstein, 1997), and tourism companies, in particular (Sundbo et al., 2007; Martínez-Ros and Orfila-Sintes, 2009). Certainly, it helps firms reach and keep higher competitiveness standards (Aldebert et al., 2011; Hjalager, 2002; Kumar et al., 2008; Pulido et al., 2011; Rodgers, 2007; Zach et al., 2010) as well as growth (Love et al., 2011). Not for nothing, Chen (2011), in the context of hotel management, literally points out that "innovation appears to be the only means for an organization to convert change into opportunities and thus succeed", and Malerba (2001) calls the tourism industry "a sectorial system of innovation and production". Destinations and firms not only have to compete against their competitors but they also have to consider the existence of strong heterogeneous demand looking for product and service provision adapted to its specific needs. Obviously, customers must perceive a hotel as satisfactory to be selected (Ngai and Watt, 2003) but, as Hua et al. (2009) suggest, tourists “are more than ever before looking for 'new' and 'unique' experiences". Thus, the existence of demanding clients that are not willing to pay a price for a product/service that they can find somewhere else with the same quality but at a lower price, the increment of pro-active consumers who seek unique experiences, along with intense competition, increase the demand for better service, better adapted to people's individual needs and, therefore, call for constant, ongoing innovativeness. In fact, Öztayşi et al. (2009) justify the importance of innovation to hotels by focusing on customers' decision process, their loyalty towards the hotel and firm competitiveness.

In a recent article, however, Hjalager (2010) qualifies innovation research in tourism as a young phenomenon, suggesting several research gaps that should be tackled in order to get further insights that contribute to consolidating the theoretical underpinnings of tourism innovation. Specifically, this author points out, among others, a research gap in tourism innovation that should attract more analysis: the relationship between innovation actions and their economic performance. This author explicitly raises the question of examining "what types of innovation produce what type of results". In an attempt to add to the extant body of knowledge on the topic, this article analyzes the effect of different types of innovations on the hotel industry's market value. 
With this objective, the subsequent sections of the article are arranged as follows: Section 2 presents the literature review of innovation in the hotel industry and justifies the hypotheses; Section 3 outlines the methodology and data employed; Section 4 describes the results; and Section 5 presents the conclusions.

\section{INNOVATION IN THE HOTEL INDUSTRY}

According to Hjalager (2010), the analysis of innovation in tourism helps understand its economic dynamics and, in this regard, several authors have studied different facets of hotel innovation: Jacob et al. (2010) examine environmental innovation as a competitiveness factor, Pulido et al. (2011) identify the critical external factors that influence innovation, González and León (2001) describe the determinant factors of environmental innovations, Hashim et al. (2010) explore the relationship between hotel characteristics and Internet adoption, Orfila-Sintes et al. (2005) show the characteristics that lead hotels to innovation, and Chang et al. (2011), Chen and Cheng (2012), Davidson et al. (2006) and Martínez-Ros and Orfila-Sintes (2012) analyze innovation through human resource management practices.

In general terms, four problems affects innovation management and its current practice (Van de Ven, 1986): the human problem of managing attention, the process problem of managing ideas into good currency, the structural problem of managing part-whole relationship, and the strategic problem of institutional leadership. Interestingly, these problems are still to be disentangled today; in a more recent publication, Van de Ven and Engleman (2004) keep considering them as core aspects in managing corporate entrepreneurship and innovation. These issues can be summed up as follows: 1)The human problem of managing attention. People are so focused on their daily activities in the company that they do not pay great attention to the development of new ideas. The question here is that, unless there is a leadership intervention, organizational members focus the attention on routine, rather than innovative activities. 2) The process problem of managing ideas into good currency. While conception of innovative ideas may be an individual activity, innovation (implementing new ideas) is a collective achievement of pushing those ideas into good and wider acceptation. 3) The structural problem of managing part-whole relationships. Ideas can come from different areas of the firm, and multiple functions and resources are needed to transform an innovative idea into reality, so the question is how to put together all the "parts" to form a "whole". 4) The strategic problem of institutional leadership. There is general 
agreement that institutional leadership is needed for organization innovation, particularly when a firm has to necessarily consider alternative fashions of doing things.

Underlying in all these issues remains the relationship between innovation and performance: how can managers measure the effectiveness of the solutions to the above issues?

Innovation has been proven to be one of the most important determinants of organizational performance. Certainly, innovation activities are carried out to achieve, among others, production and marketing goals such as enhancement in product quality, production cost control, market share reinforcement, reaching new markets, production flexibility or improvement in management performance (Quadros et al., 2001; Walker et al., 2011), but innovative actions also fosters organizational learning climate with an enhancement-oriented approach with ongoing efforts aimed at reaching improvements, renewals and even learning from unsuccessful strategies (Gunday et al., 2011); note that the integrationof technical and/or administrative changes into the organizational structure permits, first, adaptation to a competitive environment in which the only thing which is guaranteed is that "the change is a constant" (Gunday et al., 2011), and second, improvement of the level of goal achievement (Damanpour and Evan, 1984). Not for nothing, Han et al. (1998) shows that innovative activities lead to organizational growth and profitability, as it allows the firms to get synergies arrived at by the combination of technical and administrative innovations.

The central point is, therefore, how to measure the innovation-performance relationship. Critical decisions made by hotel managers, such as innovation investments, are obviously aimed at increasing the value of the company and, as a final objective, the creation of profits for the firm's investors. Consequently, a value-creating decisionmaker must choose value-creating investments. When it comes to the analysis of the effect of innovation on tourism performance, research is limited (Hjalager, 2010).

The assessment of innovation on firm performance has been generally carried out through accounting measures, which rely on the figures that appear in the company's balance sheet and income statement. Even though these measures provide a historical record on the past and present situation of the firm, they can be insufficient because (Myers, 1972): i) they do not incorporate investor expectations of future profits; ii) they could lead to confusion due to the deficiencies inherent in their dependence on different conventions (e.g., rate of depreciation), which make comparisons difficult; iii) 
they do not reflect all the opportunity costs supported by the firm; and iv) they do not allow the adjustment of differences in performance for differences in the risk supported by the firms.

Alternatively, Orfila-Sintes and Mattsson (2009) -following Álvarez et al. (2001)- measure performance through the average of occupancy rate, and attempt to explain it by employing historical data on innovation (specifically, an aggregated measure of innovation over the last three years). These authors attempt to identify the determinant factors that lead hotels to choose among four different types of innovations (service scope, back-office, management and external communication), and find that additional services on offer, booking made through tour operators, hotels being within a hotel chain and hotel ownership are explanatory factors of the types of innovation decisions. Additionally, they study the impact of innovation on performance. In this analysis, they test the effect of the aforementioned types of innovation on hotel average occupancy rate, finding that greater performance is achieved by hotels that stand within a network of business relationships with both tour operators and chains, and whose ownership is in total control of outlays and new services (Orfila-Sintes and Mattsson, 2009). In general terms, they find, as expected, a positive impact of innovation on performance.

With a different approach, this article relies on market value. Market value has the advantage that it is based on growth prospects: assuming that shareholders behave rationally, share prices should reflect the present value of future cash flows and, therefore, it constitutes a good indicator to measure the impact of innovation activities on firm performance. Market value is defined as the product of the number of shares by the share price, which is considered to be the best-unbiased estimate of the value of any investment. Market value analyses, such as the event study method, are founded, in the portfolio theory of financial economics, on the premises that stock markets are efficient and that a company's share price reflects its strategy (e.g. innovation). In an efficient stock market, share prices reflect all the available information on a company. In fact any information received by the market (e.g. on innovation activities) will be instantly incorporated into the share price. Likewise, any change to a company's share price will reflect, without bias, alterations to its future cash flows. Therefore, the introduction of new information on innovation allows an examination of share price behavior to explicitly analyze the underlying change to unbiased market predictions on future 
returns on the said innovation activity. This allows separation of returns derived from innovation activity by isolating it from the impact of other events. Accordingly, the use of market value facilitates the analysis of the effect of innovation on performance by estimating unbiased market predictions on future profits. As outlined later, market value is a forward-looking firm performance that overcomes all the difficulties of the traditionally used backward-looking firm profitability (such as accounting measures).

Additionally, when measuring innovation effects, it is important to consider innovation variety. Martínez-Ros and Orfila-Sintes' (2009) emphasize the strong heterogeneity and wide array of complex and highly innovative activities conducted in services. Certainly, the distinction of innovation types is not a straightforward task, especially because some of them might be intertwined, resulting a more complex combination of effects (Hjalager, 2010; Oslo Manual, 2005). By far, the two most used classifications are the incremental vs. radical innovations (Dewar and Dutton, 1986), and the Schumpeterian taxonomy (Schumpeter, 1934; Oslo Manual, 2005). The former distinguishes between incremental and radical innovation in such a way that incremental entails a "linear, cumulative change in a process or product, representing minor improvements or simple adjustments in current technology" while radical is a "nonlinear, paradigmatic changes, representing significant departures from existing practice or knowledge”. The latter distinguishes product innovation, process innovation, organizational innovation and marketing innovation. According to Hjalager (2010), the Schumpeterian taxonomy has been more intensively used in tourism in order to look for innovation types and analyze their effects. For example, Hall's (2009) study complies with OECD's four categories innovation in line with the Schumpeterian approach and Hjalager (1997) provides a basic categorisation close to Schumpeter's original one (product innovations, classical process innovations, process innovations in information handling, management innovations, and institutional innovations). Hjalager (2010) also indicates that distribution innovations and institutional innovations are attempts to incorporate specificities of innovation in tourism. Following this trend, this article focuses on the OECD's four categories, which are next described and exemplified with cases obtained from the sample used:

Product Innovation, is the "introduction of a good or service that is new or significantly improved with respect to its characteristics or intended uses. This includes significant improvements in technical specifications, components and materials, 
incorporated software, user friendliness or other functional characteristics. Product innovations can utilize new knowledge or technologies, or can be based on new uses or combinations of existing knowledge or technologies" (Oslo Manual, 2005). Note that the notion "product" encompasses goods as well as services, and in either case, it implies a complex process influenced by technology development, shifts in customer needs and wants, length of product life cycles and degree of global competition (Gunday et al., 2011). As Akova et al. (1998) indicates, it implicitly leads to the observation of a strong interaction with all the decision areas within the firm and the firm with its customers and suppliers. A product innovation involves the improvement of a product or service, which is critical for firms (Lenfle and Midler, 2009) and quintessential to their success (Malhotra et al., 1996), and is materialized in changes directly observed by the client and is considered to be new (Hjalager, 2010). When NH Hotels set up the "plug \& play" Internet system it was a novelty back at the turn of 2000 that added an extra service to the room itself; likewise, when this company installed the first "nhube restaurant" in their premises in 2003 it was a new concept widely acknowledged by their patrons (see Table 1). In the same vein, Sol Meliá has recently launched the Yhi Spa brand which again adds extra value to its core product. These are all new products/services in the shape of innovations that imply an investment but, at the same time, are expected to generate greater turnover.

Process innovation "is the implementation of a new or significantly improved production or delivery method. This includes significant changes in techniques, equipment and/or software. Process innovations can be intended to decrease unit costs of production or delivery, to increase quality, or to produce or deliver new or significantly improved products" (Oslo Manual, 2005). Note that, according to Gunday et al. (2011), process innovations are linked to technological developments. On this account, special mention should be made of the role of ICT as a prevalent element in hotels' process innovation, which is considered a critical investment in today's tourism system. As before, all these innovations come with a cost that is expected to be subsequently paid-off. In fact, note that the emphasis of process innovation is made on its cost-cutting nature (Fagerberg et al., 2004); that is, a basic objective of process innovation is to reduce costs irrespectively of the expected demand (e.g. Sol Meliá once announced that was going to take part in Endesa's Energy Program to learn how to efficiently use energy in their hotels). 
Organizational innovation is "the implementation of a new organizational method in the firm's business practices, workplace organization or external relations. Organizational innovations can be intended to increase a firm's performance by reducing administrative costs or transaction costs, improving workplace satisfaction (and thus labor productivity), gaining access to non-tradable assets (such as noncodified external knowledge) or reducing costs of supplies" (Oslo Manual, 2005). In other words, it considers the introduction of new organizational methods within the firm so as to improve its operational practices, which are related with administrative efforts aimed at renewing the organizational routines, procedures, mechanisms, or systems, and promoting teamwork, information sharing, coordination, cooperation, collaboration, learning and innovativeness (Gunday et al., 2011). This type of innovation activity is not only important for the firm's day-to-day operations but it is also especially relevant for tourism companies that attempt to keep their best personnel from being lured away by competitors; or simply to make their engagement in the company stronger (Ottenbacher and Gnoth, 2005; Hall and Williams, 2008). As examples, both NH and Sol Meliá have established variable monthly salaries for their staff depending on the share price or on the objectives accomplished.

Marketing innovation is "the implementation of a new marketing method involving significant changes in product design or packaging, product placement, product promotion or pricing. Marketing innovations are aimed at better addressing customer needs, opening up new markets, or newly positioning a firm's product on the market, with the objective of increasing the firm's sales" (Oslo Manual, 2005). It entails actions such as detecting new segments, redesigning promotional messages or introducing new alternative pricing methods (Ladany, 1996). A constant activity within this category is exemplified by loyalty programs (Hjalager, 2010). An example of this strategy is the "NH World" loyalty program, which allows the participant to not only enjoy specific advantages (e.g., express check-in) but to get personalized services as his/her preferences are known by the company. Certainly, loyalty programs are a consequence of the appearance of one-to-one marketing, which entails individual consideration of consumers and a one-by-one service. This approach is the basic pillar of relationship marketing -and, therefore, the application of CRM (Customer Relationship Management)-, which is designed to create, strengthen and maintain relationships between companies and their customers, in order to maximize income per 
customer. Also, within this marketing innovation realm, the advent of the Internet had a huge impact on tourism intermediaries, not only because providers can now get in touch with their customers directly but also because traditional wholesalers, such as Global Distribution Systems, can distribute their whole range to their potential clients with no intermediaries (e.g., Sabre sells to the final consumer through Travelocity). The latter marketing innovation is so important that it has led tourism literature to consider “distribution innovations" as a separate category (Hjalager, 2010 p.2). In fact, Daghfous and Barkhi (2009) indicate and Scaglione et al. (2009) prove that the role of new technologies in hotel services, operations and strategy is a critical component to reach a high level of both excellence and revenues. The relevance of distribution innovation favors its inclusion in any analysis of innovation types in the hotel industry, as in this article.

\subsection{Hypotheses development}

According to the previous literature review, two hypotheses are stated concerning the innovation-performance relationship.

Hypothesis 1. The development of the first hypothesis justifies such relationship. In general terms, there is agreement on the positive relationship between innovation and performance (Orfila-Sintes and Mattsson, 2009), on account of the higher probability of survival (Hall and Williams, 2008), higher competitive edge gained (Victorino et al., 2005), the differentiation reached (Walsh et al., 2008) and cost reductions attained (Chan et al., 1998). As Quadros et al. (2001) and Walder et al. (2011) indicate, innovation allows companies to achieve improvement in different facets such as quality, costs, market share or production, among others; all of these advantages leading to improve organizational growth and profitability (Han et al., 1998). Therefore, according to the literature review in the previous section and the above research showing a positive relationship between innovation-related activities and performance, hypothesis 1 states that:

\section{H.1. Innovation has a positive effect on hotel market value}

Hypothesis 2. The second hypothesis considers innovation diversity and performance. Within the analysis of the effect of innovation on performance, Hjalager (2010) stresses the need to examine "what types of innovation produce what type of results". At this point, it is important to emphasize the fact that not all innovations are 
equal or have the same implications (Amable and Palombarini, 1998; Tether, 2001; Zach and Fesenmaier, 2009), which is why Hjalager (2010) claims that more research is needed to evaluate the potential differentiated effect of innovation types on performance. Certainly, on account of the different innovation types, the key question is which one is expected to have a greater impact on firm market value. No universal statement can be established, since there are differences both between and within innovation types. A priori, no ranking among product, process, organization and marketing innovations can be set as it all depends on the amount of costs and sales expected. So far, abstract affirmations have been stated such as, process innovations are more influential than product innovations (Hjalager, 2002; Weidenfeld et al. 2010), hotels introducing new technological systems of delivery experience cost reductions (Chan et al., 1998), process, delivery and organizational changes are the usual innovations in hotels (Jacob et al., 2003), or demand increases are expected -and, in turn, net profits- when implementing new energy systems (González and León, 2001). As stated, it is not straightforward to make general assertions on the issue. On the one hand, an innovation is introduced with the expectation of generating higher demand: one could argue that an improvement might increase the loyalty of customers and increase chances of gaining new ones, in line with Deming (1986), which, subsequently, is translated into a larger market share. On the other hand, however, the high cost that might be implied by the new investment has a strong effect especially on industries with huge fixed costs, like the hotel sector -this fact makes hotels strongly revenuedependent (Graham and Harris, 1999)-. Consequently, on account of the different nature of each innovation type and their effects on costs and sales, hypothesis H.2 states that:

H.2. Different innovation types undertaken by hotel companies have different effects on their market value.

\section{METHODOLOGY}

The methodology is built on the following two stages: first, estimation of abnormal returns, in which several sub-steps are followed; and second, detection of differences in innovation types.

Stage 1) The abnormal returns on a sample of innovations are estimated through an event study, which implies the identification of the date of the first announcement. Event studies base their formulation on the idea that a particular event, such as an innovation announcement, affects the value of a firm; therefore, the objective is to 
observe the variation in hotel market value as a consequence of an innovation announcement on the day of the release.

Accordingly, an event-study method aims to estimate excess returns generated by a sample of unanticipated events -the basic hypothesis is that abnormal returns reflect stock market reaction to the arrival of new information-; defining each event as an innovation announcement. The event study measures the impact of unanticipated events on share prices, being based on the estimation of a market model for each company event and on the posterior calculation of abnormal returns. Specifically, the event study technique is based on the following data collection process (McWilliams and Siegel, 1997):

i) The first step detects the innovation activities carried out by the only two hotel companies trading in the Spanish Stock Market between 1996 and 2008, Sol Meliá and NH Hotels. The Factiva database is used, which provides information on headlines and news items published in different newspapers of international and national coverage, as well as those of general and/or specialized content. To this end, a combination of key words is used, such as the "company name", "innovation", "innovate", "novelty", "new product", "new service", "new process", "new procedure", "new system", "new technology", among others. The event day is defined as the first day in which the news is divulged in any of the publications used for the database. The search detects a sample of 24 innovations (see Table 1).

\section{Table 1 about here}

ii) The second step uses a 5-day-long event window to test for any abnormal behavior in company share returns; i.e., the five days before and after $(-5,+5)$ the announcement date are considered. The reason to use an event window rather than just a single day lies on the fact that, although it is expected that the majority of innovation information is quickly incorporated into share prices, it occasionally either leaks out before formal publication or is held back.

iii) The third step looks for possible confounding news published in the event window, such as takeover bids, profit announcement, dividend declarations, split announcements, complaints, claims, government contracts, court cases, or labour disputes, etc. Fortunately, no such news items are found in the event window. Although this sample size could a priori seem somewhat small, the usual empirical applications of 
the event study technique show that it is large enough to detect reactions in share prices (see for example, Gómez (2001)). Also, it is important to stress the fact that the data collection process guarantees that these are all the news items released during the study period.

iv) The fourth step estimates the market model after collecting data on market measures of performance, i.e. returns on the share price. Different frequencies (daily, weekly, monthly, annually, etc.) might lead to distinct measures, but the daily news collection procedure employed claims the use of daily returns). Market measures provide information on the value of the firm. Such data are not themselves free of problems, given that some markets may present inefficiencies or volatility on specific occasions (Ramírez and Espitia, 2001). But, they permit consideration of opportunity costs, risk supported by the firm, and capitalized value (expectations) of the profits of innovation activities, as well as to minimize the distortions resulting from tax laws and accounting standards.

The raw data are the daily returns on the shares of the two firms which made the 24 innovation announcements during the period July 2, 1996 to 31 December 31, 2008, a temporal period defined by the availability of daily stock market information. These daily returns are adjusted with dividends, subscription rights and splits. The returns on the share price of a company $i$ on day $t\left(R_{i t}\right)$ are expressed as:

$$
R_{i t}=\alpha_{i}+\beta_{i} R_{m t}+\varepsilon_{i t}
$$

where $R_{m t}=$ returns on the market portfolio on day $t$ (this study uses the IBEX-35, a representative index of the Spanish Stock Market; the information is obtained from the Stock Exchange Society); $\alpha_{i}=$ returns on the shares of company $i$ independent of those of the market; $\beta_{i}=$ sensitivity of returns on the share $i$ to variations in market returns; and $\varepsilon_{i t}=$ error term that follows an autoregressive conditional heteroskedasticity model, $\operatorname{GARCH}(1,1)$, so that $\varepsilon_{i t}=h_{i t}{ }^{1 / 2} \eta_{i t}$, where $\varepsilon_{i t} / \varepsilon_{i t-1}, \varepsilon_{i t-2}, \ldots \sim \mathrm{N}\left(0, h_{i t}\right), \eta_{i t}$ is identically and independently distributed with $\mathrm{E}\left(\eta_{i t}\right)=0$ and $\mathrm{E}\left(\eta_{i t}^{2}\right)=1$, and $h_{i t}=c_{i}+\lambda_{i} \varepsilon_{i t-1}^{2}+\gamma_{i} h_{i t-1}$, with $c_{i}$, $\lambda_{i}$ and $\gamma_{i}$ being parameters to be estimated. The estimation of equation (1) calculates daily abnormal returns (AR) for a company $i$ announcement:

$$
A R_{i t}=R_{i t}-\left(a_{i}+b_{i} R_{m t}\right)
$$

where $a_{i}$ and $b_{i}$ are the estimations of the regressions (1) for a period $T$ before the event. 
v) The last step tests abnormal returns. To analyze the effect of a company's innovation announcements on its share price, this article tests the significance of the average abnormal returns for the hotels' innovation announcements in the event window $(-5,+5)$ using Brown and Warner's (1980) and Jaffe's (1974) tests.

Brown and Warner's test is the basic test, and therefore, it is the starting point to potentially detect abnormal returns. This test is defined as

$$
t_{1}=\frac{\sum_{i=1}^{N} A R_{i}}{\sqrt{\sum_{t=1}^{N} \sigma_{\varepsilon_{i}}^{2}}}
$$

where $N$ is the number of news releases, $A R_{i}$ is the abnormal returns on the event date, and $\sigma_{\varepsilon_{i}}^{2}$ is the variance of the share $i$ obtained from the estimation period.

Also, Jaffe's (1974) test is used in this analysis. The choice of this test is justified because of the potential presence of contemporary correlation problems in the sample selected, which may be derived, on one hand, from the existence of overlapped periods for some of the news releases on different stocks and, on the other hand, from the fact that some of the companies included in the analysis belong to the same industry. Remember that, as the empirical analysis in this study is focused on the hotel sector, the firms used in the analysis belong to the same industry. These problems may well cause a biased estimate as Collins and Dent (1984) and Bernard (1987) have demonstrated, and can be avoided by Jaffe test, which is defined as:

$$
t_{2}=\frac{\sum_{i=1}^{N} A R_{i}}{\sqrt{\sum_{t=1}^{N} \sigma_{\varepsilon_{i}}^{2}+\sum_{i=1}^{N} \sum_{\substack{j=1 \\ i \neq j}}^{N} \sigma_{\varepsilon_{i} \varepsilon_{j}}}}
$$

where $N$ and $A R_{i}$ are as described before, and $\sigma_{\varepsilon_{i}}^{2}$ and $\sigma_{\varepsilon_{i} \varepsilon_{j}}$ respectively, are the variance and the covariance of the shares $i$ and $j$ obtained from the estimation period.

Stage 2) Once the abnormal returns have been estimated and tested, a regression analysis is used to detect differences in the effects of each innovation type (product, process, organizational and marketing -together with distribution innovations-). 


\section{RESULTS}

Table 2 shows the estimation of the average abnormal returns of the 24 announcements in several event windows. The results obtained demonstrate that, on average, innovation announcements are associated with positive excess returns on the post-event days; in particular, both tests -Brown and Warner, and Jaffe- present significant values in the window $(+0,+3)$. This means that, on average, firms announcing innovation activities undergo a minimum gain of $1.53 \%$ on the days after the announcement. This delay seems plausible as innovation announcements can motivate investors to re-examine a company's product positioning and strategy. It seems that they make a positive valuation of the innovations once they are re-evaluated, and react accordingly. This result supports hypothesis H.1 that innovation has a positive effect on a hotel's market value, which is in line with the positive relationship between innovation and performance found by Hall and Williams (2008), Victorino et al. (2005), Walsh et al. (2008), Chan et al. (1998) and Orfila-Sintes and Mattsson (2009).

\section{Table 2 about here}

Once the abnormal returns are estimated and tested, the analysis whether the distinct innovation types have differentiated effects on these abnormal returns is performed. Table 3 shows the results of the regressions conducted. Two equations are estimated: one with the traditional classification for innovations (product, process, organization and marketing) and another in which "distribution innovations" are extracted from "marketing innovations" so that they can be treated separately as a different category, in line with Hjalager (2010). Organization innovations are used as the base reference for the parameter estimation. Both equations have a global level of significance of $1 \%$, whose adjusted R-squared measures explain $41.7 \%$ and $44.9 \%$, respectively, and the two equations show robust results: the significant parameters shows consistent signs in both equations and their significance levels are the same.

\section{Table 3 about here}

As for the individual parameters, "process" and "marketing" innovations are found to be significantly greater than both "product/service innovations" and the reference category "organization innovations". These greater returns are confirmed in the two equations. Also, chi-square tests find that there are no significant differences between "process" and "marketing" innovations in Equation 1, and among "process", 
"marketing" and "distribution" innovations in Equation 2. These specific sizes of innovation impacts confirm hypothesis H.2 that different innovation types undertaken by hotel companies have different effects on their market value; however, note that what is actually found is that "product/service innovations" (0.033) are not dissimilar from "organization innovations" (0.000), which are different from "process innovations" (0.104) and "marketing innovations (0.079) -with and without distribution innovations (0.060)-", which in turn are similar. That is, in this particular application "process and marketing innovations" exert a higher impact on market value than "product/service and organization innovations": product innovations like the new "nhube restaurants" (e.g., NH Hotels, March 3, 2003) and organization innovation such as "variable salaries subject to share price variations" (e.g., NH Hotels, April 4, 2007 and Sol Meliá, June 6, 2004) might entail extra costs that might be regarded by investors as high. Certainly, "loyalty programs" such as the issue of loyalty cards with advantages for the clients like getting earlier or staying later than normal guests, or allowing them to speed up the check-in process (e.g., NH Hotels, October 10, 2004) within marketing innovations do not require (in relative terms, of course) such high investment, while an increase in sales is expected. Note, however, that a company's "energy commitments" (e.g., Sol Meliá, May 6, 2003 and April 7, 2008) within process innovations should parallel "product" and "organization" innovations in terms of costs; that is, high costs should be expected and therefore not-so-high returns should be obtained. Nevertheless, it is important to remember that the potential increment in sales should also be taken into account, especially for the specific news items observed that are related to environmental issues. Note that there is a green trend today (Chou et al., 2012; Dubois et al., 2011; Han et al., 2011; Han and Kim, 2010; Kang et al., 2012; Pizam, 2010; Rahman et al., 2012) and an environmentally-friendly wave blowing all over the business realm in the framework of social corporate responsibility that might lead investors to perceive this investment as less risky; in fact, consumers tend to favor socially responsible firms (Bhattacharya and Sen, 2003) and, when it comes to pro-environmental actions, positive relationships have been found between these green investments and hotel performance (García and Armas, 2007). In this regard, for these particular news types, the prospect of future sales might compensate the high costs implied, in line with the net benefit derived from implementing new energy systems evidenced by González and León (2001). In any case, the important result from this posterior analysis revolves around the fact that not 
all innovations are equal, and neither are their implications. Each innovation should be considered individually by managers, both between and within categories.

\section{CONCLUSIONS}

In today's Darwinian environment, innovation is a cornerstone for every firm in the tourism industry. Innovations not only allow them to survive in the market but to show everybody (mainly, their clients) that they are still alive. In this regard, this article attempts to measure the effect of innovation on hotel market value. The results show that innovations are perceived to have a positive impact on the future sales of the company (note that market value is a future-oriented measure of cash-flow). Specifically, in a four-day period (from day 0 to day +3 ), there is an increase in returns of $1.53 \%$; what is more, $1.53 \%$ in four days is equivalent to annual returns of $300 \%$.

Also, in an attempt to further explain these returns derived from innovations, the news items are categorized into the four traditional types: product, process, organization and marketing (plus distribution). "Process" and "marketing" (and "distribution") innovations have a higher positive effect on the market value than "product" and "organization" innovations. This reveals that each innovation needs to be treated differently and individually, not only between but within categories, on account of cost differences among innovations.

Implications: Beyond the specific results of the empirical application, the study has important implications, both academic and managerial. Regarding academic implications, the finding that a hotel's market value varies when the prospect of innovation activities is announced indicates that this measure can be regarded as appropriate to analyze this type of investments. This fact, along with the outcome that these variations in hotel market value are contingent upon the type of innovation, suggests that, when a comprehensive examination is pursued by the analyst, different types of innovation and distinct kinds of measurements should be employed. While innovation types are expected to lead to different results, the use of several performance measures might allow the researcher to find hidden effects that, otherwise, would not be easy to uncover. Note that, in the end, using distinct performance measures implies looking at the company from different perspectives; perspectives that represent facets that might be worth looking into them. As for managerial implications, the use of market value facilitates the analysis of the effect of innovation on performance by estimating unbiased market predictions on future profits. This technique employs a 
forward-looking firm performance that overcomes all the difficulties of the traditionally used backward-looking firm profitability, i.e., accounting measures. Specifically, once the innovation is announced, managers might observe the evolution of share prices to determine how valuable the news is perceived to be by the shareholders. If the shareholders' perceptions of it are not as good as the managers would have expected, they may want to see whether this is due to a lack of information (or even to misinformation). If this were the case, a new flow of information should be released, in order to clarify the hotel's innovation. Also, finding that innovation has a positive impact on firm market value means that the market considers that an innovative company is a healthy firm. Therefore, any tourism company introducing innovations, no matter whether they are internal or external, should show that it is innovating all the time, by releasing news through a well-executed public relations system.

Limitation. Even though the process followed to collect the innovation news announcements in the hotel industry guarantees that, a priori, all of them must have been detected, the resulting sample size is a clear limitation; not so much because it affects its ability to capture potential reactions in share prices, but because it does not allow the inclusion of a larger number of potential explanatory variables that could shed further light on the innovation-related determinants of hotel market value.

Future research. For further research, several lines can be followed in order to provide a more comprehensive view of the relationship between innovation and market value in the hotel industry:

1) The paper has used the Schumpeterian classification to identify differentiated effects in innovation types; nevertheless, the use of other taxonomies would offer a broader view in terms of academic perspectives (as it would permit the identification of the best explanatory classification) as well as in terms of management perspectives (as it would show decision-makers the best innovation types according to the taxonomy used).

2) A larger sample would permit the use of factors related to a hotel's characteristics; for example, the same innovation might have different effects on a hotel performance depending on its category (e.g. number of stars). 
3) The analysis of the effect of innovation on distinct tourism-related industries would show whether the same type of innovation has a differentiated influence (hotels, travel agencies, airlines, etc).

4) The use of specific information on each innovation, especially in terms of costs incurred in the investment could shed more light on the specificities of every initiative; that is, knowing the cost invested in an innovation could determine how costly (per unit) the variations in market value are.

5) Risk analysis. Some innovation decisions are particularly relevant as sometimes they can imply enormous investments; this fact, together with the large amount of fixed costs generally involved in the hotel industry, makes them strongly revenue-dependent, which might lead to profit instability. Consequently, it would be critical to examine the effect of innovation on the risk of a hotel's market value (measured through its volatility, for example).

6) There is a social trend today that favors corporate social responsibility (CSR) actions, so it would be interesting to see whether innovation oriented to enhance a hotel's CSR exerts an incremental effect on performance. That is, as the CSR literature shows that these activities have a positive impact on market value, and this article has shown that innovations have also a positive effect on market value, it would be worthwhile analyzing whether a greater effect exists when both activities -CSR and innovation- are linked together (e.g. the announcement of an innovation that allows a more efficient use of solar panels in hotels).

7) Recent literature has proven sequential interdependency between radical and incremental innovations (Martínez-Ros and Orfila-Sintes, 2009). It would be relevant to test the effect of this sequential interdependency on market value, as it would allow managers to determine the best innovation decisions (and its sequence) to optimize the firm's market value.

8) As market value has been shown to reflect innovation announcements, it is possible to analyze the effect of innovation-based competitive reactions on the firm. In other words, as the market value captures the hotel's innovation strategy, it could be expected that it will reflect the competitor's innovation strategy too. It would facilitate a rivalry analysis between actions and reactions based on innovation strategies. 
9) Innovation is supposed to enhance customer satisfaction, and it should be reflected in the "opinion polls" that are shown in most hotels' web pages these days. On the one hand, the value or ranking obtained in these polls can be used as alternative measure of innovation effectiveness; and on the other, correlation analyses between the value/ranking obtained through these perceptions and a hotel's market value would show whether variations in market value are materialized in real terms too.

10) With the advent of new technologies, other measurements of innovation impact can be used. If "twitter" were treated as a market where information is exchanged, and the number of "tweets" were considered as a measure of repercussion (or hype), it could be interesting to observe the expectations generated by an innovation announcement on a specific day. Paralleling the method employed in this article, it would imply observing whether the amount of "exchanged information" (tweets) derived from a firm's release of news on a given day is abnormally superior to the quantity of "exchanged information" in a normal day, and whether and how many good things are said. 


\section{REFERENCES}

Akova, B., Ulusoy, G., Payzın, E., Kaylan, A.R., 1998. New product development capabilities of the Turkish electronics industry. In: Proceedings of the Fifth International Product Development Management Conference, Como, Italy, pp. 863-876.

Aldebert, B., Dang, R.J., Longhi, C. 2011. Innovation in the tourism industry: The case of Tourism@. Tourism Management, 32 (5), 1204-1213.

Álvarez, M.J., Burgos, J. and Céspedes, J.J., 2001. An analysis of environmental management, organizational context and performance of Spanish hotels, Omega, $29(6), 457-471$.

Amable, B. and Palombarini, S., 1998. Technical change and incorporated R\&D in the service sector, Research Policy, 27 (7), 655-675.

Bhattacharya, C.B. and Sen, S., 2003. Consumer-Company Identification: A Framework for Understanding Consumers' Relationships with Companies. Journal of Marketing, 67, 76-88.

Brown, S. and Warner, J., 1980. Measuring Security Price Performance. Journal of Financial Economics, 8, 205-258.

Chan, A., Go, F. M., and Pine, R., 1998. Service innovation in Hong Kong. Attitudes and practice. The Service Industries Journal, 18 (2), 112-124.

Chang, S., Gong, Y. and Shum, C., 2011. Promoting innovation in hospitality companies through human resource management practices, International Journal of Hospitality Management, 30 (4), 812-818.

Chen, W.J (2011. Innovation in hotel services: Culture and personality, International Journal of Hospitality Management, 30 (1), 64-72.

Chen, W.J. and Cheng, H.Y., 2012. Factors affecting the knowledge sharing attitude of hotel service personnel, International Journal of Hospitality Management, 31 (2), 468-476.

Chou, C.J., Chen, K.S., and Wang, Y.Y., 2012. Green practices in the restaurant industry from an innovation adoption perspective: Evidence from Taiwan, International Journal of Hospitality Management, forthcoming.

Daghfous, A. and Barkhi, R., 2009. The strategic management of information technology in UAE hotels: An exploratory study of TQM, SCM, and CRM implementations, Technovation, 29 (9), 588-595.

Damanpour, F., Evan, W.M., 1984. Organisational innovation and performance: the problem of "organisational lag", Administrative Science Quarterly, 29 (3), 392409.

Davidson, M., Guilding, C. and Timo, N., 2006. Employment, flexibility and labour market practices of domestic and MNC chain luxury hotels in Australia: Where has accountability gone?, International Journal of Hospitality Management, 25 (2), 193-210.

Deming, E., 1986. Out of the crisis. MIT Center for Advanced Engineering Study. Boston.

Forsman, H., 2011. Innovation capacity and innovation development in small enterprises. A comparison between the manufacturing and service sectors Research Policy, 40 (5), 739-750.

Gallouj, F. and Weinstein, O.,1997. Innovation in services. Research Policy, 26 (4-5), 537-556.

Gallouj, F., 2002. Innovation in the service economy. Elgar, Cheltenhan, UK, Northampton, USA. 
García, F.J. and Armas, Y.M., 2007. Relation between social-environmental responsibility and performance in hotels firms, International Journal of Hospitality Management, 26 (4), 824-839.

Gómez, J.C., 2001. Rentabilidad y liquidez alrededor de la fecha de desdoblamiento de las acciones, Investigaciones Económicas, 25 (1), 171-202.

González, M. and León, C.J., 2011. The adoption of environmental innovations in the hotel industry of Gran Canaria. Tourism Economics, 7 (2), 177-190.

Gunday, G., Ulusoy, G., Kilic, K., Alpkan, L. 2011. Effects of innovation types on firm performance, International Journal of Production Economics, 133 (2), 662-676.

Hall, C. M., 2009. Innovation and tourism policy in Australia and New Zealand: never the twain shall meet?. Journal of Policy Research in Tourism, Leisure and Events, 1 (1), 2-18.

Hall, C. M., and Williams, A. M., 2008. Tourism and innovation. London: Routledge.

Han, H. and Kim, Y., 2010. An investigation of green hotel customers' decision formation: Developing an extended model of the theory of planned behavior, International Journal of Hospitality Management, 29 (4), 659-668.

Han, H., Hsu, L.T.J., Lee, J.S. and Sheu, C., 2011. Are lodging customers ready to go green? An examination of attitudes, demographics, and eco-friendly intentions, International Journal of Hospitality Management, 30 (2), 345-355.

Han, J.K., Kim, N., Srivastava, R.K., 1998. Market orientation and organisational performance: is innovation the missing link?, Journal of Marketing, 62 (4), 3045.

Hashim, N.H., Murphy, J., Purchase, S. and O'Connor, P., 2010. Website and email adoption by Malaysian hotels, International Journal of Hospitality Management, 29 (1), 194-196.

Hipp, C. and Grupp, H., 2005. Innovation in the service sector: The demand for servicespecific innovation measurement concepts and typologies, Research Policy, 34 (4), 517-535.

Hjalager, A. M., 2002. Repairing innovation defectiveness in tourism. Tourism Management, 23 (5), 465-474.

Hjalager, A.-M., 1997. Innovation patterns in sustainable tourism - an analytical typology. Tourism Management, 18 (1), 35-41.

Hjalager, A.M., 2010. A review of innovation research in tourism. Tourism Management, 31 (1), 1-12.

Hua, M.L.M, Horng, J.S, and Sun, Y.H.X (2009. Hospitality teams: Knowledge sharing and service innovation performance. Tourism Management, 30 (1), 41-50.

Jacob, M., Florido, C. and Aguiló, E., 2010. Environmental innovation as a competitiveness factor in the Balearic Islands. Tourism Economics, 16 (3), 755764.

Jacob, M., Tintoré, J., Aguiló, E., Bravo, A., and Mulet, J., 2003. Innovation in the tourism sector: results from a pilot study in the Balearic Islands. Tourism Economics, 9 (3), 279-295.

Jaffe, J.F., 1974. Special information and insider trading. Journal of Finance, 47, 410428.

Kang, K.H., Stein, L., Heo, c.Y. and Lee, S., 2012. Consumers' willingness to pay for green initiatives of the hotel industry, International Journal of Hospitality Management, 31 (2), 567-572.

Kumar, U., Kumar, V. and Grosbois, D., 2008. Development of technological capability by Cuban hospitality organizations, International Journal of Hospitality Management, 27 (1), 12-22. 
Ladany, S.P., 1996. Optimal market segmentation of hotel rooms - the non-linear case, Omega, 24 (1), 29-36.

Lenfle, S. and Midler, C., 2009. The launch of innovative product-related services: Lessons from automotive telematics, Research Policy, 38 (1), 156-169.

Love, J.H., Roper, S. and Bryson, J.R., 2011. Openness, knowledge, innovation and growth in UK business services, Research Policy, 40 (10), 1438-1452.

Malerba, F., 2001. Sectoral systems of innovation and production: concepts, analytical framework and empirical evidence. In: ECIS conference the future of innovation studies, Eindhoven, September 20-23.

Malhotra, M.K., Grover, V. and Desilvio, M., 1996. Reengineering the new product development process: A framework for innovation and flexibility in high technology firms, Omega, 24 (4), 425-441.

Martínez-Ros, E. and Orfila-Sintes, F., 2009. Innovation activity in the hotel industry, Technovation, 29 (9), 632-641.

Martínez-Ros, E. and Orfila-Sintes, F., 2012. Training plans, manager's characteristics and innovation in the accommodation industry, International Journal of Hospitality Management, forthcoming.

McWilliams, A. and Siegel, D., 1997. Event Studies in Management Research: Theoretical and Empirical Issues. Academy of Management Journal, 40 (3), 626-57.

Myers, S., 1972. The Application of Finance Theory to Public Utility Rate Cases. The Bell Journal of Economics and Management Science, 3 (1), 58-97.

Ngai, E.W.T and Wat, F.K.T., 2003. Design and development of a fuzzy expert system for hotel selection, Omega, 31 (4), 275-286.

Orfila-Sintes, F. and Mattsson, J., 2009. Innovation behavior in the hotel industry, Omega, 37 (2), 380-394.

Orfila-Sintes, F., Crespí-Cladera, R. and Martínez-Ros, E., 2005. Innovation activity in the hotel industry: Evidence from Balearic Islands, Tourism Management, 26 (6), 851-865.

Oslo Manual, 2005. Proposed Guidelines for Collecting and Interpreting Technological Innovation Data, OECD.

Ottenbacher, M., and Gnoth, J., 2005. How to develop successful hospitality innovation. Cornell Hotels and Restaurant Administration Quarterly, 46 (2), 205-222.

Öztayşi, B., Baysan, S. and Akpinar, F., 2009. Radio frequency identification (RFID) in hospitality, Technovation, 29 (9), 618-624.

Pizam, A., 2009. Green hotels: A fad, ploy or fact of life?, International Journal of Hospitality Management, 28 (1), 1.

Pulido, J.I., Sáez, A. and Figueroa, C., 2011. Critical external factors behind hotels' investments in innovation and technology in emerging urban destinations. Tourism Economics, 17 (2), 339-357.

Quadros, R., Furtado, A., Roberto, B., Franco, E., 2001.Technological innovation in Brazilian industry: an assessment based on the Sao Paulo innovation survey. Technological Forecasting and Social Change, 67, 203-219.

Rahman, I., Reynolds, d. and Svaren, S., 2012. How "green" are North American hotels? An exploration of low-cost adoption practices, International Journal of Hospitality Management, forthcoming.

Ramírez, M. and Espitia, M., 2001. The Effect of International Diversification Strategy on the Performance on Spanish-Based Firms during the Period 1991-1995. Management International Review, 41 (3), 291-315.

Rodgers, S., 2007. Innovation in food service technology and its strategic role, International Journal of Hospitality Management, 26 (4), 899-912. 
Scaglione, M., Schegg, R. and Murphy, J., 2009. Website adoption and sales performance in Valais' hospitality industry, Technovation, 29 (9), 625-631.

Schumpeter, J.A., 1934. The Theory of Economic Development. An Inquiry into Profits, Capital, Credit, Interest, and the Business Cycle. Harvard University Press, Cambridge.

Sundbo, J., Orfila-Sintes, f. and Sørensen, F., 2007. The innovative behaviour of tourism firms - Comparative studies of Denmark and Spain, Research Policy, 36 (1), 88-106.

Tether, B.S., Hipp, C. and Miles, I., 2001. Standardisation and particularisation in services: evidence from Germany, Research Policy, 30 (7), 1115-1138. Innovation in services

Van de Ven, A. and Engleman, R., 2004. Central problems in managing corporate innovation and entrepreneurship. Advances in Entrepreneurship, Firm Emergence and Growth, 7, 47-72.

Van de Ven, A., 1986. Central problems in the management of innovation. Management Science, 32 (5), 590-607.

Victorino, L., Verma, R., Plaschka, F., and Dev, C., 2005. Service innovation and customer choices in the hospitality industry. Managing Service Quality, 15 (6), $555-576$.

Walker, R.M., Damanpour, F., Devece, C.A. 2011. Management Innovation and Organizational Performance: The Mediating Effect of Performance Management, Journal of Public Administration Research Theory, 21 (2), 367386.

Walsh, K., Enz, C. A., and Canina, L., 2008. The impact of strategic orientation on intellectual capital investments in customer service firms. Journal of Service Research, 10 (4), 300-317.

Weidenfeld, A., Williams, A.M., Butler, R.W., 2010. Knowledge transfer and innovation among attractions. Annals of Tourism Research, 37 (3), 604-626.

Zach, F. and Fesenmaier, D.R., 2009. Innovation in Tourism: The Case of Destination Marketing Organizations, e-Review of Tourism Research (eRTR), 7 (1), 27-36.

Zach, F.; Ulrike, G. and Zheng, X., 2010. Innovation in the Web Marketing Programs of American Convention and Visitor Bureaus, Information Technology \& Tourism, $12(1), 47-63$. 
Table 1. Announcements of the innovation activities (chronological order)

\begin{tabular}{|c|c|c|c|c|}
\hline & Date & Firm & Type & Announcement \\
\hline 1 & 26/09/1997 & $\mathrm{SM}$ & 3 & $\begin{array}{l}\text { Sol Meliá has a new online service: an employment exchange to which those interested in being part of the chain may send their } \\
\text { curriculum vitae. }\end{array}$ \\
\hline 2 & 25/11/1997 & $\mathrm{SM}$ & 3 & $\begin{array}{l}\text { Just over } 30 \% \text { of the staff of the corporate services of Sol Melia have accepted that part of his salary is paid according to } \\
\text { objectives. This method, which turns a percentage of the former fixed payments into variable, will be implemented gradually to } \\
\text { all the staff. }\end{array}$ \\
\hline 3 & 20/03/1999 & $\mathrm{SM}$ & 4 & $\begin{array}{l}\text { The hotel chain Sol Meliá has launched a new service to arrange reservations of the golf courses and help its clients practice this } \\
\text { sport. }\end{array}$ \\
\hline 4 & $01 / 03 / 2000$ & $\mathrm{SM}$ & $4^{*}$ & $\begin{array}{l}\text { The hotel chain Sol Meliá will use the intermediation of a computerized reservation system (CRS), Amadeus, Sabre, Galileo and } \\
\text { Worldspan, to enter the electronic commerce through the Internet }\end{array}$ \\
\hline 5 & $29 / 12 / 2000$ & $\mathrm{NH}$ & 1 & $\begin{array}{l}\text { NH Hotels and Recoletos Group have reached an agreement through which the hotel chain offers Telva magazine to their } \\
\text { customers for free. This new service will be available in especially equipped rooms for executive women. }\end{array}$ \\
\hline 6 & $08 / 02 / 2001$ & $\mathrm{NH}$ & $4 *$ & $\begin{array}{l}\text { NH Hotels has added to its website an online reservation center. This new service works in a similar way to the reservation } \\
\text { telephone system that the chain set up three years ago. }\end{array}$ \\
\hline 7 & 29/06/2001 & $\mathrm{SM}$ & 1 & $\begin{array}{l}\text { Sol Meliá announced yesterday that it will enter the catering business through a corporation, Meliá Catering SA, which was born } \\
\text { a year and a half ago. The company is headquartered at the Meliá Barcelona Hotel and has three hubs, Palma, Mérida and } \\
\text { Madrid, to cover the entire country. The idea is to use Sol Meliá customers to offer them a new service. }\end{array}$ \\
\hline 8 & $14 / 08 / 2001$ & $\mathrm{NH}$ & 1 & $\begin{array}{l}\text { The hotel chain NH Hotels has launched the system "plug \& play" that provides Internet connection speed up to } 56 \text { Kbps, and } \\
\text { allows working without having to install any software on the laptop with a flat rate }\end{array}$ \\
\hline 9 & $07 / 03 / 2003$ & $\mathrm{NH}$ & 1 & $\begin{array}{l}\text { Gabriele Burgio inaugurated the first "nhube" yesterday, a pioneering space in the hotel industry, combining restoration, rest and } \\
\text { leisure, which has been designed by the prestigious Spanish restaurateur Ferrán Adriá. }\end{array}$ \\
\hline 10 & $06 / 05 / 2003$ & SM & 2 & $\begin{array}{l}\text { Endesa, the largest Spanish electricity supplier, has developed an Energy Advisory Program directed specifically to the hotel } \\
\text { sector to help entrepreneurs to identify and implement more efficient technologies in the use of energy and water. The first } \\
\text { companies that have chosen this new service are the Majorcan hotel chains Blau Hotels, Sol Meliá, Mac Hotels, Globalia and } \\
\text { Pins Hotels. }\end{array}$ \\
\hline 11 & $29 / 05 / 2003$ & SM & 3 & $\begin{array}{l}\text { Sol Meliá launches new advisory service for clients to hold and organize meetings, conventions, conferences and incentives } \\
\text { trips. }\end{array}$ \\
\hline 12 & $25 / 09 / 2003$ & SM & 1 & $\begin{array}{l}\text { The hotel chain Sol Meliá will allow customers of some of the best hotels of the brand in Spain to be able to access Internet for } \\
\text { free from its rooms and meeting rooms with broadband connection. }\end{array}$ \\
\hline
\end{tabular}


Table 1. (cont.)

\section{Date Firm Type}

\section{Announcement}

$1307 / 11 / 2003 \mathrm{NH} \quad 1 \quad$ NH Hotels will present the new Internet access system that has been implanted in their hotels.

$1408 / 06 / 2004$ SM 3 The board of shareholders of Sol Meliá has approved today a new remuneration system for senior management of the company linked to the value of the chain's stock price.

The NH hotel chain, chaired by Gabriele Burgio, will invest 700,000 euros in technology to expand its Internet booking system.

15 25/06/2004 NH 4* With the new service, the company aims to increase the reserves of stays made by business travelers, as it will allow them to reduce paperwork and facilitate the hiring of hotel nights.

NH Hotels has launched a new loyalty program called NH World, whose main novelty lies in the smart card that is incorporated,

$1615 / 10 / 2004 \mathrm{NH} \quad 4 \quad$ which speeds up the registration procedures on the premises and stores all customer information and preferences, customizing their services to them.

17 17/01/2005 NH $\quad 1 \quad$ NH Hotels has launched a new modality in its offer for urban entertainment called "Weekends with Content", oriented to companies that hold events at their facilities, conventions, seminars and incentive trips.

18 22/01/2005 NH $4 * \quad$ NH Hotels has implemented a new exclusive Information and Reservation Center.

$1903 / 10 / 2005$ NH $1 \quad$ NH Hotels opens, with additional novelties, its second Fast Good in Madrid

$2011 / 05 / 2006 \mathrm{NH} \quad 1 \quad$ NH Hotels Group continues its commitment to gastronomy and has created a new breakfast buffet service.

21 02/09/2006 SM 1 Sol Meliá launches "Royal Service" for its clients to be "at home" at the Gran Meliá Volcán Lanzarote

22 07/03/2007 SM 1 Sol Meliá launches the brand Yhi Spa for health and welfare

23 24/04/2007 NH $3 \quad$ NH will implement a reward system for its managers linked to the value of its shares.

24 07/04/2008 SM 2 Sol Meliá and ALSA register their voluntary commitments to reduce CO2 emissions on a new system.

Types: 1=product; 2=process; $3=$ organization; 4=marketing; $4 *=$ Distribution innovation 
Table 2. Abnormal returns tests

Window Abnormal returns (\%) Brown and Warner`s test Jaffe`s test

\begin{tabular}{cccc}
\hline$(-5,+5)$ & 0.831 & 0.698 & 0.730 \\
$(-5,-1)$ & -0.044 & -0.054 & -0.057 \\
$(-5,0)$ & 0.413 & 0.474 & 0.496 \\
$(-3,0)$ & 0.243 & 0.339 & 0.355 \\
$(-1,0)$ & 0.287 & 0.566 & 0.592 \\
$(+1,+5)$ & 0.414 & 0.515 & 0.539 \\
$(0,+1)$ & 0.641 & 1.261 & 1.321 \\
$(0,+3)$ & 1.539 & $2.144^{\mathrm{a}}$ & $2.244^{\mathrm{a}}$ \\
$(0,+5)$ & 0.875 & 0.995 & 1.041 \\
\hline \hline $\mathrm{a}=$ prob $<5 \%$ & & &
\end{tabular}

$\mathrm{a}=$ prob $<5 \%$ 
Table 3. Innovation type and Performance

\begin{tabular}{ccccccccc}
\hline \hline & $\begin{array}{c}\text { Product } \\
\text { /service } \\
\text { Innovations }\end{array}$ & $\begin{array}{c}\text { Process } \\
\text { Innovations }\end{array}$ & $\begin{array}{c}\text { Marketing } \\
\text { Innovations }\end{array}$ & $\begin{array}{c}\text { Distribution } \\
\text { Innovations }\end{array}$ & Constant & $\mathbf{R}^{2}$ & $\begin{array}{c}\text { Adjusted } \\
\mathbf{R}^{2}\end{array}$ & $\begin{array}{c}\text { F- } \\
\text { statistic }\end{array}$ \\
\hline Eq. 1 & 0.033 & $0.104^{\mathrm{a}}$ & $0.079^{\mathrm{a}}$ & & $-0.033^{\mathrm{c}}$ & 0.493 & 0.417 & $6.505^{\mathrm{a}}$ \\
& $(0.019)$ & $(0.032)$ & $(0.020)$ & & $(0.017)$ & & & \\
Eq. 2 & 0.024 & $0.098^{\mathrm{a}}$ & $0.108^{\mathrm{a}}$ & $0.060^{\mathrm{b}}$ & -0.026 & 0.545 & 0.449 & $5.694^{\mathrm{a}}$ \\
& $(0.019)$ & $(0.031)$ & $(0.028)$ & $(0.024)$ & $(0.017)$ & & &
\end{tabular}

$\mathrm{a}=$ prob $<1 \% ; \mathrm{b}=$ prob $<5 \% ; \mathrm{c}=$ prob $<10 \%$ 